\title{
PRACTICE, POWER AND MEANING: FRAMEWORKS FOR STUDYING ORGANIZATIONAL CULTURE IN MULTI-AGENCY RURAL DEVELOPMENT PROJECTS
}

\author{
DAVID LEWIS $^{1}{ }^{*}$, ANTHONY J. BEBBINGTON ${ }^{2}$, SIMON P. J. BATTERBURY ${ }^{3}$, ALPA SHAH ${ }^{1}$, \\ ELIZABETH OLSON $^{4}$, M. SHAMEEM SIDDIQI ${ }^{5}$ and SANDRA DUVALL ${ }^{6}$ \\ ${ }^{1}$ London School of Economics and Political Science, London UK \\ ${ }^{2}$ Institute for Development Policy and Management, University of Manchester, Manchester, UK \\ ${ }^{3}$ University of Arizona, Tucson, USA \\ ${ }^{4}$ University of Colorado at Boulder, Boulder, USA \\ ${ }^{5}$ CARE, Dhanmondi, Dhaka, Bangladesh \\ ${ }^{6}$ Consultant, Ougadougou, Burkina Faso
}

\begin{abstract}
Culture has received increasing attention in critical development studies, though the notion that there are important cultural differences within and between development organizations has received less consideration. This paper elaborates elements of a framework for studying organizational culture in multi-agency development projects. It draws on selected writings in anthropology and in organizational theory and suggests that these two bodies of literature can be usefully brought together, as well as on insights from ongoing fieldwork in Bangladesh, Burkina Faso and Peru. At the centre of this framework is the analysis of context, practice and power. Where development projects involve multiple organizations (such as donors, government agencies, non-governmental organizations and grassroots groups) an analysis of cultures both within and between organizational actors can help explain important aspects of project performance. The paper argues that organizational culture is constantly being produced within projects, sometimes tending towards integration, often towards fragmentation. This fragmentation, indicative of the range of cultures within development organizations, is an important reason why some projects fail, and why ideas stated in project documents are often not realized, especially in the case of the newer and more contentious objectives such as 'empowerment'. Copyright (C) 2003 John Wiley \& Sons, Ltd.
\end{abstract}

\footnotetext{
*Correspondence to: D. Lewis, Centre for Civil Society, Department of Social Policy, London School of Economics, Houghton Street, London WC2A 2AE, UK. E-mail: d.lewis@1se.ac.uk
} 


\section{INTRODUCTION}

The purpose of this paper is to explore frameworks for understanding the interactions among different actors within development projects that say they aim to empower organizations of the poor. In particular, the paper considers the extent to which a more explicit focus on the cultures of different organizations involved in such interventions leads us to reflect on issues of power and agency in ways that may help better explain the final effects that projects have, and the extent to which they remain congruent with or veer away from their stated objectives. This may also offer explanations that are slightly more contingent than those in much of the critical development literature. Furthermore, we will suggest that such a focus draws us towards a clearer understanding of the different perspectives that are at play in projects - and a more complex understanding than one based primarily on an analysis of project documents. While it is not our intention to suggest that such questions of organizational culture are the only factors in explaining the effects of interventions, we do wish to suggest that a focus on organizational culture may help reveal other and often under-appreciated dimensions of project processes.

The significance of questions of culture in development processes has received increasing attention, above all in the critical anthropology of development literature. By tracing the links between culture, knowledge and power, this work has offered insights into processes of knowledge formation, project conception and implementation that technocratic and managerial literatures in development did not. We hope to build on some of these insights by bringing this literature into conversation with the literature on organizational culture. We suggest that this may help provide rather more specific and 'operationalizable' ways for thinking about culture and the links between culture and practice which might then be helpful for analysing processes within and between development agencies, rural populations and other actors. ${ }^{1}$

The paper begins with a brief discussion of the research project on which our arguments are based, and we then review what seem to us to be particularly useful contributions to the understanding of development intervention, both from work in the anthropology of development and from research from organizational theory. These reviews then form the basis for a closing discussion of ideas that might underlie a framework combining the analysis of organizational culture, power relationships and human agency in the study of development interventions.

\section{ORGANIZATIONAL CULTURE AND EMPOWERMENT IN MULTI-AGENCY DEVELOPMENT PROJECTS}

The framework developed in this paper was first elaborated at the onset of a three country research project to study the influence of organizational culture on the effects of World Bank funded rural development projects that identify the empowerment and strengthening of community based organizations as one of their goals. ${ }^{2}$ The ideas presented in this paper

\footnotetext{
${ }^{1}$ 'Rural' because that is our focus in the research on which this paper is based, and is also our own area of competence. This is not to imply that such approaches might not also be helpful for thinking about the interactions between organizations and urban populations: it is merely to limit our claims to our competencies.

${ }^{2}$ This research was funded as one of a number of studies funded under the Culture and Development research programme managed by the Poverty and Social Development groups of the World Bank, with funds from the Trust Fund on Culture and Poverty, financed by the Netherlands Ministry of Foreign Affairs. However, the views expressed are the authors' own.
} 
are based on fieldwork conducted in Bangladesh, Burkina Faso and Peru between early 2001 and mid-2002, presently being written up, as well as on broader literature on organizational culture and the anthropology of development. Brief reference is made to examples from emerging case study data in Section 4 below.

Although both terms are contested, culture and empowerment have made recent significant appearances in research and policy at the World Bank (Kanbur, 2002). The Bank's World Development Report 2001 made an explicit commitment to the idea that development intervention should foster empowerment of the poor (World Bank, 2000; see also Moore, 2001) at the same time as fostering economic opportunity and security. Given this openly-stated commitment, we were interested not only in whether Bank-funded projects could enable empowerment of the poor, but also the extent to which the organizational conditions of the Bank and its partners themselves would actually permit Bank-funded projects to deliver on these empowerment commitments. The central hypothesis of the research was that one key reason why projects may not succeed in meeting empowerment objectives is, quite simply, a disjuncture between discourse and practice. This is because in projects that involve multiple agencies (as most Bank projects tend to do) commitments to empowerment objectives made by funders and NGOs or other agencies cannot easily be sustained in the course of project implementation. One important explanation might be that any agreed upon meanings (discourse) in project documents quickly diverge during implementation (practice), because of fragmentary tendencies within the cultures and practices of the organizations involved.

In view of the diverse understandings of the concept of 'empowerment', we chose to work with a relatively loose definition of the term. ${ }^{3}$ The projects we studied were all rural development programs that involved multiple actors and combined material objectives (income enhancement, sustainable natural resource management) with varying types of socio-political objectives (strengthening landless peoples' groups, changing gender relations, fostering local governance of natural resources, or increasing the access that base groups have to public resources). In each of the countries in which we worked, we chose rural development projects that had an explicit commitment to organizational strengthening, participation and empowerment (Table 1). Another criterion for project selection was that it had to have been operating for at least two years in order that we would be able to observe some of the organizational processes involved, and their early effects.

The research approach was motivated by the increasing call for detailed ethnographies of development organizations (see next section). Although there were different approaches adopted in each of the three country studies, in each case it was possible to observe and interact with a variety of institutional processes, although without the longer-term participant observation associated with more detailed anthropological studies. Our research was qualitative in nature, based on semi-structured interviews with key informants at organizational and village levels, organizational and village level focus groups, participant observation of project and organizational processes, multi-stakeholder workshops and analysis of project documents. ${ }^{4}$ It is on that basis that we elaborate our

\footnotetext{
${ }^{3}$ As a result, what we considered an empowerment objective might be viewed by others simply as a commitment to local organizational strengthening and participation. Nonetheless, it seemed appropriate to first ask whether the Bank could even deliver on less contentious notions of empowerment before considering other more radical definitions employed by activist organizations.

${ }^{4}$ Fieldwork was conducted by a combination of locally-based local and expatriate researchers and the project coordinators.
} 
Table 1. Projects studied

\begin{tabular}{|c|c|c|}
\hline Country & Project and dates of operation & Project aims \\
\hline Bangladesh & $\begin{array}{l}\text { Silk Development Pilot Project } \\
(1997-)\end{array}$ & $\begin{array}{l}\text { To reform public sector sericulture support } \\
\text { institutions and to improve research and } \\
\text { extension services to poor non-traditional } \\
\text { female silk producers who have been organized } \\
\text { by NGOs into grassroots producer groups. }\end{array}$ \\
\hline Peru & $\begin{array}{l}\text { Natural Resource Management and } \\
\text { Poverty Alleviation Project (1998-), } \\
\text { part of the World Bank's support to the } \\
\text { National Program for the Management of } \\
\text { Watersheds and Soils (PRONAMACHS) }\end{array}$ & $\begin{array}{l}\text { To foster watershed-based management of } \\
\text { natural resources and the strengthening of } \\
\text { community based organizations linked to } \\
\text { environmental management. }\end{array}$ \\
\hline $\begin{array}{l}\text { Burkina } \\
\text { Faso }\end{array}$ & $\begin{array}{l}\text { Pilot component (1998-) within the } \\
\text { Second National Agricultural Service } \\
\text { Project (PNDSA II), along with sub- } \\
\text { components of The National Land } \\
\text { Management Program (PNGT Phase 1), } \\
\text { where the implementing agencies in rural } \\
\text { areas were NGOs rather than the state. }\end{array}$ & $\begin{array}{l}\text { To test new ways of channelling funds directly } \\
\text { to farmers' organizations for the selection } \\
\text { and implementation of villagers' own initiatives; } \\
\text { support to community - level environmental } \\
\text { management initiatives and to village-level } \\
\text { natural resource management committees and } \\
\text { their work }\end{array}$ \\
\hline
\end{tabular}

following comments on existing frameworks for understanding organizations, and that we present our own framework for analysing the effects of organizational culture on project interventions. The more detailed ethnographies of each project are currently under preparation as country reports which will be adapted for future publication.

\section{ANALYSING PROJECT PROCESSES: INSIGHTS FROM ETHNOGRAPHY AND ORGANIZATIONAL THEORY}

Prior to initiating this research, some of us had already argued that work in the anthropology of development that emerged in the last two decades (Ferguson, 1990, 1997; Escobar, 1995; Long and Long, 1992), while helpful and intriguing, only generates a partial understanding of the nature and effects of development intervention (Gardner and Lewis, 1996, 2000; Bebbingon, 2000; Bebbington et al., 2000; Batterbury, 1998). One possible way of complementing these insights could, we believed, be drawn from a closer engagement with business management and organizational theory, and particularly those studies directly addressing issues of culture and agency (Lewis, 2002). In the following two sections we therefore first review contributions from the more ethnographic approaches to development intervention, and their potential for illuminating our understanding of project and intervention processes; we then review potentially helpful concepts from studies in organizational theory. ${ }^{5}$

\footnotetext{
${ }^{5}$ The latter is a potentially fruitful theme which has not been particularly well integrated into thinking about development projects, despite occasional references to it in work in development studies (e.g. see Biggs and Smith, 2002; Maxwell, 1997). We recognise that both of these literatures are extensive, and here we selectively review what seem to us to be potentially helpful contributions. We are of course aware of other literature such as anthropological work on the state (e.g. Scott, 1998; Benei and Fuller, 2001) which may be relevant to our discussion but for reasons of space have not considered such work here.
} 


\subsection{Ethnographic Approaches to Development Organizations}

While anthropologists and others have long been concerned to bring an ethnographic perspective to the development process (Ferguson, 1997; Gardner and Lewis, 1996; Olivier de Sardan, 1995; Rhoades, 1984; Drinkwater, 1991), it is only more recently that this perspective has been brought to bear on development organizations and interventions themselves (as opposed to the 'objects' of development, for example peasants, women, or the urban poor). And it remains the case that even now ethnographic studies of development organizations are relatively few in number. Arguably, there are still many more calls for ethnographies of development organizations (Cooper and Packard, 1997a; Markowitz, 2001; Watts, 2001) than there are such ethnographies. ${ }^{6}$

Nonetheless the increased interest in ethnographic analysis of development organizations relates to the recent evolution of the globalization research agenda. The more that it has been argued that the dynamics of globalization processes need to be explained and elaborated rather than just invoked, the more it becomes important to understand in ethnographic detail the activities, but also the political and economic rationales, of the principal agents of globalization including international financial institutions, transnational corporations, and NGOs (Burawoy et al., 2000; Wade, 2003).

Though still germinal, these lines of ethnographic enquiry have opened up interesting conceptual and methodological agendas for studying development organizations. The following paragraphs review some of these with a view to setting out elements of a conceptual framework in section four of this paper.

\subsubsection{Development organizations as text}

Central to the post-structural analysis of development has been to understand development as a discourse - a system of knowledge, technologies, practices and power relationships that serves to order and regulate the objects of development and, at the same time, serves to demarcate what can and cannot be done and said within development (Ferguson, 1990; Escobar, 1995; Moore, 2001). ${ }^{7}$ Texts such as planning documents, strategic frameworks, project documents, sector reports and the like are read by the ethnographer with a view to tracing the ways in which the language and concepts used in such texts close out certain ways of thinking and viewing the world, while privileging others. Analyses typically draw out the likely practical effects of these ways of knowing and seeing, in general showing the effects to be detrimental to the objects of this knowledge (rural people, for instance), but advantageous for the deepening of capitalist development and the interests of the state and other dominant institutions. Tracing the 'instrument-effects' (Ferguson, 1990) of such practices helps reveal the system of power relationships that underlies not only the production of development texts but also the broader enterprise of development.

The two most acclaimed studies in this vein are James Ferguson's (1990) study of a rural development project in Lesotho, and Arturo Escobar's (1995) analysis of development more broadly. By forcing a more careful and critical scrutiny of texts produced by

\footnotetext{
${ }^{6}$ This is not least because of the logistical and methodological difficulties of being able to 'get inside' such organizations in order to study them-especially if the researcher has traditionally had a critical stance towards development. Organizations do not easily and willingly open doors to such researchers (Bebbington, 2002).

${ }^{7}$ Within much of this work, a Foucauldian concept of power has been deployed to throw light on the ways in which power pervades systems of relationships at all levels of social norms and cultural practices and customs and not merely at the 'centre'. It is this conception of power, which challenges more traditional dichotomies of 'macro' and 'micro' or 'powerful' and 'powerless', which informs our study.
} 
development organizations they oblige the reader to challenge assumptions about how and why development organizations operate as they do, encouraging reflection on the way in which development organizations and practices are necessarily caught up in relationships of power that transcend development per se (Harriss, 1997). As such they force more critical interpretations of the links between development organizations and broader political economic processes.

Yet often, such studies offer relatively few ethnographic details on the workings of the development organizations that they discuss, and how these workings influence the texts they produce and the practices they effect (Watts, 2001). This is particularly so for those parts of their analyses that discuss international development organizations. In this regard, the organizations remain as black boxes in these studies, and as a result, causal mechanisms are under-specified.

\subsubsection{Actor-oriented approaches to development organizations}

The actor-oriented approach has in part attempted to open this black box (Long and Long, 1992; Arce and Long, 2000; Hebinck and Verschoor, 2001; Nuijten, 1992, 2001). The concern of this work has been to understand how meanings associated with development are produced, contested and reworked in practice — and thus to illuminate the multiple significances that the term holds for actors involved in the development process. In examining such questions, this work has thrown considerable light on how national and local development bureaucracies function-and how this functioning leads almost inevitably to significant slippages between development goals as laid down in policy and project documents, the goals pursued in operational practice, and the personal goals pursued by 'clients' and local bureaucrats in the course of implementing (or 'performing') projects (Long, 1992, p. 34).

If such slippage between development text and effect is so prevalent, then the implication is that analysis of practice must accompany analysis of text if one is to fully understand how development organizations produce ideas, how slippage occurs in their translation into practice, and the material effects of this. In the actor-oriented research program, studying project interventions (and the organizations responsible for them) thus assumes a central position:

The concept of intervention thus needs deconstructing so that it is seen for what it is

- an ongoing, socially constructed and negotiated process, not simply the execution

of an already-specified plan of action with expected outcomes. (Long, 1992, p. 35).

This approach allows for more discussion of agency than one in which the analysis of discourse is central (Bebbington, 2000).

A second actor-oriented tradition of scholarship that has also addressed processes at the interface between development agencies and rural populations is the largely francophone work associated with the Euro-African Association for the Anthropology of Social Change and Development (APAD) under the intellectual leadership of the anthropologist JeanPaul Olivier de Sardan and colleagues. ${ }^{8}$ This work is relevant to our concerns since it also insists on the importance of understanding the concrete links between culture, practice and power. This is a deeply empirical tradition, less critical than some of the work discussed above and instead arguing that it is important to accept

${ }^{8}$ For a more detailed review of this research tradition, see Batterbury (2002). 
... that 'development' in Africa exists on the ground, is unlikely to suddenly disappear, and ... actually offers new openings for particular classes or groups to increase their power base in rural society (Batterbury, 2002, p. 22).

The focus on the ways in which people operate, both as staff of development agencies and as members of the societies where agencies are intervening, leads to a nuanced notion of the fragmented culture of development organizations, and opens up the possibility of change within development processes, especially where rural people become skilled development actors and therefore retain power over processes and meanings (Laurent, 1998; Lund, 1998).

Finally, and although not formally ethnographic, Tendler's (1997) work is also relevant to our discussion, since it displays a longstanding interest in the inner workings of development. Tendler's study of the sources of effective government in NE Brazil aimed to understand how innovation had occurred within several government programs in the state of Ceará by focusing on the actions of bureaucrats and project staff along the chain of project implementation, focusing on incentives and motivation-what led officials and staff to act in ways that favoured client orientation, responsiveness and program effectiveness? Such concerns led to a further question-how could one explain the changes in organizational incentives and behaviour that had led to effective programs. This theme often took Tendler's analysis to specific innovators and individuals who had taken risks within bureaucracies - and who had often had the authority to effect change. Analytically the dissatisfying part of such an approach is that explanations often end up depending on the presence of innovators who are able to change the formal and informal rules within a development bureaucracy and so change the incentives structuring the behaviour of large numbers of staff. ${ }^{9}$ Nonetheless, the lesson of this work is that following actors and their actions, and developing long-term research engagements with and within particular institutional environments makes it possible for the researcher to deliver explanations of the feel of organizations with a level of descriptive detail that organizational studies rarely achieve. ${ }^{10}$

\subsubsection{Embedding the actor, grounding discourse}

A number of studies aim to combine elements of actor oriented and discursive approaches to provide ethnographic detail on how particular texts are produced by development organizations, how these interact with project practice, and the power relations involved in such processes. Indeed, power is central to these analyses, and the implication is that it is impossible to conceptualise organizational culture separately from an analysis of the power relations within the organization involved and between it and other actors. Perhaps not accidentally, the primary object of many of these studies has been the World Bank (Wade, 1996,1997; Goldman, 2001; Bebbington et al., 2000).

Goldman's (2001) study of the ways in which the World Bank has produced environmental knowledge in relation to a large intervention in Laos is particularly interesting in this regard. Goldman's concern is to '... ask how this new knowledge about the people

\footnotetext{
${ }^{9}$ Although a non-anthropologist, Tendler's work is characterised by a relatively deep level of engagement with organizations, processes and people.

${ }^{10}$ It is ironic perhaps that a political economist should produce a more revealing organizational ethnography than many anthropologists! Similarly, Sikkink's (1997) work on the production of ideas within the UN's Economic Commission for Latin America uncovers in detail the politics underlying the texts.
} 
and environment of Laos is actually produced,... [and] second,... [to] ask how it becomes authoritative, or dominant' (Goldman, 2001, p. 194). At one level these concerns are very similar to Ferguson's, though Goldman executes them differently. Text analysis is combined with a modern ethno-history of Bank presence in Laos. Using interviews with Bank staff in Washington and Ventiane (Laos), with consultants, with Laotian government officials, with NGO staff and with others in the development 'community', Goldman identifies the ways in which environmental knowledge produced by the Bank is influenced by various pressures on the process of producing this knowledge: in particular material pressures (especially lack of time), political pressures (the decision of contractors not to release reports they do not like), and financial pressures (where monetary incentives influence the knowledge that some sub-contracted researchers chose to produce in their reports). While this analysis of the incentives and pressures that derive from-and which Goldman (like Ferguson) interprets explicitly in terms of - the Bank's financial power does help explain how certain reports get produced and others not, the analysis says very little about the sociological and political processes within the Bank that generate these pressures, and make them work in the ways that they did in this case. This makes it easier for the analyst to impute a particular and largely unproblematised relationship between power and institutional practice.

Studies that have been able to get inside the Bank convey slightly more nuanced interpretations of the internal processes within the institution (Wade, 1996,1997; Bebbington et al., 2000). They resonate with actor-oriented work in that they illuminate how organizational groupings within the institution emerge out of particular practices and actor-networks, and how, under certain institutional conditions, these groupings are able to consolidate and formalize themselves within the Bank. As opposed to analyses like Goldman's that seem to imply a more or less monolithic and unitary culture within the Bank, these analyses give a greater sense of the existence of cultures, or perhaps more accurately countertendencies (c.f. Arce and Long, 2001), within the institution's overall modernist culture. These cultures are the manifestations of the concerns and characteristics of different groups or actor-networks within the organization, and they vie among themselves to exercise influence over the texts and practices that ultimately emanate from the organization. The implication is that while, from the outside, some observers view a single organization with a monolithic culture (itself in turn grounded in particular power relationships), an alternative reading would suggest that there are a range of culture/power relationships within the organization that compete, struggle and collaborate (albeit within a context of unequal power relations among them) in order to change the internal culture and external face of the organization.

\subsection{Organizational Culture in Organisational Theory}

\subsubsection{Organizational culture as integration}

'Organizational culture' in the simplest terms is 'the way of life in an organization' (Hatch, 1997, p. 204). Morgan (1997, p. 138) defines it in more complex terms as 'a process of reality construction that allows people to see and understand particular events, actions, objects, utterances, or situations in distinctive ways'. It generally refers to shared values and practices which evolve within organizations. Organizational culture is partly influenced by wider societal cultures, and is partly newly constructed, deliberately or by 
chance, by people themselves within organizations. ${ }^{11}$ There has been a sustained interest in how organizational form contributes to efficiency in business and public services, at least since 'researchers and consultants began to realise that an organization's culture was a powerful force that shaped many aspects of its behaviour' in the 1970s (Dowling, 2001, p. 105), and that a firm's organizational culture itself was shaped in part by the ways work is carried out. ${ }^{12}$ Peters and Waterman (1982) suggested that businesses would tend to operate more successfully if they built a strong unifying culture based on 'shared vision'; Kotter and Haskett went further in a study of US corporations to link the presence of an adaptive culture stressing the needs of employees and customers directly with aboveaverage financial performance (Kotter and Heskett, 1992).

This focus on culture is important outside the business sector as well, since it helps reveal organizations not as rational 'engineered' structures but as interactive groups of people:

If organizations are communities, mini-societies, rather than machines, then it is natural to expect that each community will have its own taste and flavour, its own way of doing things, its own habits and jargon, its own culture (Handy, 1988, p. 85).

Handy went on to identify four basic types of basic cultural 'styles,' which he called person culture (individuals work mainly for themselves), task culture (flexible teams of people are focused on tasks), role culture (clearly defined roles are set out within a hierarchical structure) and club culture (like-minded people loosely grouped around a charismatic leader). He used these to analyse the dominant values and practices within an organization, based on different sets of expectations within organizations about working processes.

While Handy's work points to the existence of an overall dominant 'defining' culture within a particular organization, other writers like Edgar Schein have showed how organizational culture is the ongoing outcome of adaptive and integrative efforts of people to build values and practices which can sustain an organization. In Schein's model of organizational culture (1985) there are three interacting levels: (i) artefacts, (ii) values and norms and (iii) beliefs and assumptions, each of which help to shape an organization's internal integration and external adaptation. Hawkins (1997) develops these ideas further in order to do justice to both the richness of the culture of an organization and the complexity of organizational change processes. He identifies five levels of culture within an organization: artefacts - such as policy documents, mission statements, dress codes, buildings; behaviour - such as what people do and say, what is rewarded, how conflict is resolved and how mistakes are treated; mindset-mainly the values and assumptions which inform and constrain behaviour; emotional ground-referring to the unconscious emotional states and needs which create a context within which events are perceived; and

\footnotetext{
${ }^{11}$ This tension between societal and organizational culture runs through much of this literature. The key study which seeks to link both of these is Hofstede's (1991) cross-national comparative study of IBM staff which reviews work-related values held by employees. He concluded that there was a set of wide-ranging national cultural differences displayed within IBM's offices in different countries, and that these differences were apparent within IBM's overall organizational culture. Hofstede produced a theoretical framework which set out key differences along four axes: (i) power-distance (the distance staff feel from their superiors), (ii) uncertaintyavoidance (the ways in which staff deal with novelty and risk), (iii) individualism (the level of integration of individuals into collectivist groups) and (iv) masculinity (the valuing of performance and ambition compared and contrasted with the valuing of quality of life and role flexibility). For a short review of Hofstede and some of his some of his critics in relation to 'third sector' research agendas see Lewis (2002).

${ }^{12}$ This insight of course shares much with a Marxist view in which the mode of production dictates the forms of work, with the presence of poorly paid workers in capitalist firms alongside a capitalist class.
} 
motivational roots - the underlying sense of purpose which links the organization and the individuals involved in it. Hawkins' model therefore provides a useful framework for empirical enquiry into organizational culture.

\subsubsection{Organization culture as fragmentation}

Implicit in such work is the idea that organizational culture - a shared, unifying system of values, meanings, understandings - is an integrative, binding force which holds organizations together. But Hatch (1997) reminds us that 'shared' actually has two meanings - one related to common experience, but another, as in 'dividing up' which emphasizes difference and individuality. Brown and Covey's (1983) analysis of an organization as a 'microcosm' of its environment shows how an organization contains diverse cultural perspectives, tending to reproduce internally the ideological conflicts which are characteristic of the wider society in which an organization exists. They highlight the process of 'ideological negotiation' within a US-based third sector organization working in development education, project management and government lobbying. Brown and Covey concluded that organizations ' . . cannot be efficiently co-ordinated without recognising and managing ideological diversity rooted in the cultural origins of organization members' (p. 246).

There are also likely to be sub-cultures which reveal an organization to be far more complex and contradictory than unitary views suggest (Dowling, 2001, p. 109). In recent work on fair trade relationships constructed between international for-profit business and local NGOs (Lewis, 1998b), it was found that differences between forprofit business culture and 'charitable' welfare culture generated ambiguities which offered both opportunities (in the form of new thinking which challenged existing norms and values) and problems (in the form of increased value conflicts and risks of misunderstanding).

Some post-modern organizational theorists have argued more strongly instead that organizations are culturally fragmented, and prefer to place the concepts of ambiguity and flux at the centre of the analysis of organizational culture (Alvesson, 1994). This latter view is supported by work which shows that multiple cultures may exist within an organization. DiBella (1992) for instance shows how planned organizational change within an NGO was challenged and diverted by a set of fragmented 'sub-cultures' within different parts of the organization, making outcomes unpredictable and ambiguous. Subcultures may drive an organization, but equally, they can conflict with the dominant organizational culture and prove detrimental to it (Dowling, 2001).

\subsubsection{Anthropological critiques}

The latter views are closer to those of anthropologists working on organizational studies, many of whom are critical of organization and management theorists. The organizational culture emphasis of Peters and Waterman (1982) was simultaneously welcome and problematic since, for some organization theorists at least, culture was viewed as just another variable which could be 'managed' (Wright, 1994). Indeed, Wright's (1994) work can be seen as an antidote to recent management fashions around organizational culture. She argues that culture is a process rather than 'a thing' which leads us away from viewing organizations as bounded entities seeking to accomplish tasks and challenges us to look more closely at the continuous 'process of organising,' which creates meanings and structures everyday organizational life. This perspective also emphasises the idea of 
culture not as a unitary concept, but as a complex set of conflicting sub-cultures, meanings and mindsets. Sensitivity to the political dimensions of organizational culture becomes paramount in that a dominant group may exercise power through a dominant culture or through a programme of organizational change.

A final but important anthropological critique of organizational culture questions whether culture itself is an appropriate conceptual tool for the analysis of organised action. Douglas (1992, p. 167) criticizes the tendency to use culture as an all-purpose explanation or as 'an extra resource to be wheeled in after other explanations are defeated'. Similarly, Kuper (1999) in an extended essay on anthropological views of culture, concedes that culture is best seen only as a 'partial explanation', which needs to be put alongside politics, economics and social institutions. In a comparative study of labour markets in Britain and Sweden, Douglas (1992) argues that the analysis of values and their relationship to organizational forms is far more useful than generalised notions of culture. Douglas defines culture as 'the package of values that are cited in the regular normative discussions that shape an institution' (p. 176). In highlighting the cultural differences between trade unions in Britain and Sweden, she shows how British trade unions were established within an atmosphere of opposition and distrust and adopted a 'sect' culture (bonding insiders against outsiders), while Swedish trade unions originated in a less 'conspiratorial' atmosphere and took on a 'hierarchical' culture based on their position as legitimate negotiating partners within a national political movement.

\section{PRACTICE, POWER AND MEANING: A FRAMEWORK FOR ANALYSING ORGANIZATIONAL CULTURE IN DEVELOPMENT PROJECTS}

The challenge now is to explore whether and how the concerns of these two broad literatures can be linked. With so many apparently different ways of addressing the notion of culture, it is quite understandable that some researchers prefer to avoid the term altogether. Also, as Worsley (1999, p. 30) has pointed out, the concept of culture has until recently been ignored by development theorists who were eager to escape colonial discourses of culture and the 'culturalist' explanations of modernization which represented culture as a 'barrier' to development. Yet, this aversion to addressing culture too often leads development studies-even those scholars preoccupied with institutional arrangements, incentive structures and service delivery - to ignore 'the complexity and diversity of human life' (p. 30) and to neglect the way in which culture is 'a dimension of all social action, including economic and political life' (p. 37). ${ }^{13}$ By bringing together these two literatures in this paper we hope that we have made a start in opening up new agendas in development research which are suggested through such a link.

Indeed, it remains striking how often in the course of conducting our own research on organizations, informants and lay-people would invoke the notion of culture in trying to explain how organizations operate. For example, one intermediary agency in Bangladesh was characterised as having 'an elite culture' and as 'not knowing anything about ordinary peoples' culture and conditions'. A World Bank official in Peru admitted that 'I think there

\footnotetext{
${ }^{13}$ An exception to this trend is Grindle's (1997) paper, which argued that a 'positive' organizational culture, defined as 'a shared set of norms and behavioural expectations characterizing a corporate identity', is an ingredient which may help successful public sector organizations overcome the principal-agent and staff incentive problems which beset the majority of poorly performing organizations.
} 
are incentives not to tell the truth in public'. When people make such statements, they seem to be referring to the ways in which certain types of profession see the world, to 'the way things are done around here,' to implicit hierarchies within organizations, to what can be said and what is best left unsaid, and so on. They are also often referring to a sense of history - to the way in which all these dimensions of culture are embedded in longer-term practices, both within the organization and the broader society in which it is embedded. One example of this from the Bangladesh research was the fragmentation of meanings associated with a clash between the cultures of welfare and helping which traditionally informed one local NGO with the culture of business and profit which was required to achieve financial sustainability within the project.

If organizational culture seems so important to those working within development organizations, then it is perhaps incumbent on analysts of those organizations to engage with the idea that culture matters. And if lay concepts of organizational culture arehowever implicitly - multifaceted and complex then any framework we develop to study it needs also to be multifaceted. In some sense, the different literatures briefly reviewed above each contain certain elements of what people refer to when they speak of the culture of the organizations they deal with, but at the expense of others. In this closing section we explore how far it may be possible to read across these literatures to begin developing a multi-faceted but still empirically workable framework for studying organizational culture within development projects. Elements of such a framework, albeit in tentative form, are set out in Table 2 .

Emerging from these literatures is first the sense that if we are to address organizational culture it is necessary to focus on context. Context matters because organizations are part of broader societal structures and sets of meanings: be these around management, racism, professionalism, class and so on (Harriss, 1997). These meanings are in turn embedded in broader structures of social power. However, the interpretations of organizations cannot be simply reduced to those meanings and power structures in broader society as tends to happen in studies such as Ferguson's (1990), which interpret at least some organizations (especially the World Bank) primarily on the basis of discourses and texts, relating those discourses quite directly to broader political and economic relationships. The literature on organizational culture is a helpful corrective to this take on organizations for it forces deeper analysis of the ways in which meanings are constructed within development organizations and the projects they support, and the ways in which such meanings are both stabilized and fragmented over time. For example, sub-cultures are found within the World Bank, which is not a monolithic entity. It also encourages us to ask about the links between organizational culture and a wide set of societal practices - not only those associated with the workings of political economy, but also ones related to professional formation and training, management styles and behaviour, and so on.

Secondly, a notion of practice and agency must be at the centre of any conception of organizational culture, above all if we are to avoid a much criticized but still common 'superorganic' notion of culture that hovers above actors but is attributed with causal powers in the way that Douglas (1992) criticized. It is only at the level of a study of practices that one can assess the extent to and ways in which broader societal meanings are made present within organizations. By the same token, any analysis of discourses emanating from organizations ought to be conducted through study of the practices that produced them (and of those that were marginalized in the process). Likewise, it is only through studying practices that one can understand the ways in which organizations tend towards having a more or less integrative culture shared by staff, or a more fragmentary set 
Table 2. Organizational culture and development-elements of a framework

\begin{tabular}{|c|c|c|}
\hline Key concern & Examine & Looking for \\
\hline $\begin{array}{l}\text { Divergence between text } \\
\text { and practice }\end{array}$ & $\begin{array}{l}\text { Project documents, evaluation reports, } \\
\text { appraisals. Adherence to mission statements, } \\
\text { formal rules, etc in everyday project practice }\end{array}$ & $\begin{array}{l}\text { Disjunctures, } \\
\text { inconsistencies, and } \\
\text { commonalities }\end{array}$ \\
\hline A more extensive & Workings of projects and their participants. & Innovators, brokers \\
\hline $\begin{array}{l}\text { analysis of development } \\
\text { practice }\end{array}$ & $\begin{array}{l}\text { Emergence of new cultural hybrids on the } \\
\text { interface-interlocutors, brokers, etc }\end{array}$ & $\begin{array}{l}\text { How projects tick } \\
\text { Elements of } \\
\text { bureaucratic practice }\end{array}$ \\
\hline $\begin{array}{l}\text { How meaning is } \\
\text { produced in practical } \\
\text { development settings? }\end{array}$ & $\begin{array}{l}\text { How key actors think about what they are } \\
\text { doing }\end{array}$ & $\begin{array}{l}\text { Contestation, production } \\
\text { and reworking of } \\
\text { meanings, claim-making }\end{array}$ \\
\hline $\begin{array}{l}\text { A richer sociological } \\
\text { analysis of development } \\
\text { organizations }\end{array}$ & $\begin{array}{l}\text { Presence of and formation of sub-cultures- } \\
\text { how do they emerge and why can they } \\
\text { fragment? }\end{array}$ & $\begin{array}{l}\text { Powerful, integrative, } \\
\text { disaffected and ignored } \\
\text { subcultures. Do these } \\
\text { challenge anything? } \\
\text { How? }\end{array}$ \\
\hline $\begin{array}{l}\text { Interpreting the cultural } \\
\text { style of the organization } \\
\text { to understand evolve the } \\
\text { evolution of its own } \\
\text { organizational culture its } \\
\text { potential to 'deliver' }\end{array}$ & $\begin{array}{l}\text { How organizations work-who controls, } \\
\text { who listens, presence of key cultural attributes. } \\
\text { Identify cultural styles e.g. using Handy's } \\
\text { categories and Schein's levels }\end{array}$ & $\begin{array}{l}\text { Evidence of } \\
\text { club/task/role/person } \\
\text { behaviours. Examine at } \\
\text { level of artefacts, values, } \\
\text { norms, behaviour, } \\
\text { emotions and mindsets }\end{array}$ \\
\hline $\begin{array}{l}\text { Fragmentation and } \\
\text { coalescence of meanings }\end{array}$ & All of the above before drawing conclusions? & $\begin{array}{l}\text { Questions over project } \\
\text { purpose, incomprehension, } \\
\text { unsupervised activity, } \\
\text { repeat of same answers } \\
\text { in questioning? }\end{array}$ \\
\hline Context of organizations & $\begin{array}{l}\text { Understand the social context in a given locale, } \\
\text { and look for similarities in a development } \\
\text { organization active in region. i.e. } \\
\text { embeddedness of social norms in the } \\
\text { organization, and its effect on outcomes, } \\
\text { effectiveness, practice. Do local norms conflict } \\
\text { with those of funding/intermediary } \\
\text { organizations, for example? }\end{array}$ & $\begin{array}{l}\text { Similarities and } \\
\text { differences in agency } \\
\text { and practice, revealing } \\
\text { possible social and } \\
\text { political inevitabilities } \\
\text { (like hierarchies or } \\
\text { bureaucracies } \\
\text { developing) }\end{array}$ \\
\hline $\begin{array}{l}\text { Balance of power in } \\
\text { multi-agency projects }\end{array}$ & $\begin{array}{l}\text { Structure of organization, evaluation of key } \\
\text { stakeholders }\end{array}$ & $\begin{array}{l}\text { Mapping power-who } \\
\text { controls or dominate } \\
\text { others? Good } \\
\text { communication between } \\
\text { key organizations? }\end{array}$ \\
\hline
\end{tabular}

of sub-cultures. And finally, it is only through a study of practice that it becomes possible to understand how and why organizations are given the meanings that they are given by people beyond the organization. ${ }^{14}$

\footnotetext{
${ }^{14}$ Understanding the links between practice and the process of producing meanings both within, and of, organizations is also important for operational reasons. If organizational culture is to be acted upon in any effort to mobilize, change or otherwise use organizations then understanding how culture relates to material practices is essential in order to identify the practices that must be worked in any intervention. For example, comments from one sericulture group in Bangladesh suggests evidence of a learning culture intertwined with elements of dependency on NGO staff: 'If we make a mistake, like if we don't recognise when the silkworm is sleeping, we go to the NGO workers and ask them what to do. The worker corrects the mistake and explains how to do it properly'. Unpacking these relationships in detail is essential if progress is to be made towards the project objective of 'empowerment of the poor'.
} 
Of course, human agents within organizations are also themselves embedded in broader social relationships, just as is the organization itself. This is well understood in some of the literature referred to in this paper, for example in work on the brokers, or intermediaries who sit between aid donors and NGOs (Bierschenk et al., 2000). But, likewise, the practices of these agents are influenced by the structures (rules, incentives, norms etc) of the organization in which they are executed. Recognizing this is important. It cautions that the actions of agents - members of farmer organizations, for example — are determined at least in part by their participation in that organization, rather than being determined by their position in society and politics at large. Also, it reminds us to avoid a completely voluntarist sense of agency, in which organizational culture(s) are produced by wholly autonomous agents who produce whichever meanings they may choose.

This tension between practice and embeddedness is the familiar one between agency and structure (c.f. Giddens, 1979) and which, in our particular case, boils down to the question: do agents or structures produce meanings within and associated with organizations? Of course the answer must be that both do, particularly when we consider that contexts are created by actors at various 'moments' in time and space, the effects of which might continue as structure. Where the relative weight of explanation lies and how far agents break free of structures (in the way Tendler showed they can do) thus becomes an empirical question. These are questions that can only be addressed through the sort of ethnographic study of organizations implied in the work of Long, APAD, Tendler and others. A particular challenge is thrown up where analysis is of multi-agency projects and the relationships between different organizations. If cultures of organization matter-as we have argued they do-then the matrix of organizational cultures and their interactions, clashes, and commensurability will contribute to explanations of the success or failure of particular development interventions. In the examples of projects researched by our team, it was found in all cases that 'success' was impaired by a fragmentation of meaning between actors embedded in different organisations. ${ }^{15}$

Despite these observations, any conceptualisation of organizational culture must still engage with the concept of power: within and between organizations, and also within society at large. Which values and meanings become dominant in a development project - and, whether projects can deliver on an empowerment agenda - is largely a question of the balance of power among different interest groups in and surrounding the organizations which are implementing the programmes. This is a theme both in critical development anthropology and organizational studies. The ways in which these power relationships are ultimately worked out, and the routes through which particular meanings come to prominence, is an empirical question. This means tracing project histories carefully, and charting the interactions among different agencies, the values and meanings prioritised and struggled for by groups within each agency, and the ebbs and flows of particular meanings regarding the purpose to which project resources should be put. This, for us, should form the basis for a future research agenda on the organization and the culture of development interventions.

\footnotetext{
${ }^{15}$ Perhaps the most extreme difference we encountered was between the rule-bound systems of the World Bank procurement department and the handling of small amounts of credit in farmers groups in rural Burkina Faso. As one would expect, the chain linking these two groups was lengthy, and each worked to different — fragmentedunderstanding s of accounting procedures. The result was less the generation of shared cultural understanding and the achievement of 'development' through external funding, than a breakdown in understanding, resulting in the early termination of the project. Although the WB staff clearly have more 'power' in this relationship, our focus on the workings of organizational culture would suggest that it was the lack of shared meaning - and not just the power to determine the actions of others - that accounted for this situation.
} 


\section{REFERENCES}

Alvesson G. 1994. Culture and Organizations. Cambridge University Press: Cambridge.

Arce A, Long N. 2000. Anthropology, Development and Modernities. Routledge: London.

Batterbury SCE. 1998. Top-down meets Bottom-up: Institutional Performance and the Evaluation/ Monitoring of the EU's SME Policies in Galicia and Sardinia. D.Phil Thesis, University of Sussex.

Batterbury SPJ. 1998. Local environmental management, land degradation and the Gestion des Terroirs approach in West Africa; policies and pitfalls. Journal of International Development 10: 871-898.

Batterbury SPJ. 2002. A discursive review of Courtiers en développement: Les villages africains en quête de projets. Environment and Planning D: Society and Space 20(1): 20-25.

Bebbington AJ. 2002. Reflexes sobre a relação Norte Sul na construção de conhecimentos sobre as ONGs na América Latina. ABONG: Sao Paulo.

Bebbington AJ. 2000. Re-encountering development: livelihood transitions and place transformations in the Andes. Annals of the Association of American Geographers 90(3): 495-520.

Bebbington AJ, Woolcock M, Guggenheim S. 2000. Mapping discourse explaining action: social capital in theory and practice at the World Bank. Paper presented at the workshop Practical Theory, Reflective Action: Social Capital and Development Projects at the World Bank, October 27-28th, 2000, Boulder, University of Colorado at Boulder.

Bierschenk T, Chauveau J-P, Olivier de Sardan J-P (eds). 2000. Courtiers en Développement: Les Villages Africains en Quête de Projets. Editions Karthala: Paris.

Bierschenk T, Olivier de Sardan J-P (eds). 1998. Les Pouvoirs au Village: le Bénin entre Democratisation et Decentralisation. Editions Karthala: Paris.

Benei V, Fuller CJ. 2001. The Everyday State: Anthropological Perspectives on the State and Society in Modern India. C. Hurst: London.

Biggs S, Smith S. 2002. A paradox of learning in project cycle management and the role of organizational culture. Unpublished paper, School of Development Studies, University of East Anglia.

Brown D, Covey J. 1983. Organizational microcosms and ideological negotiation. In Negotiating in Organizations, Bazerman MH, Lewicki RJ (eds). Sage Publications: Newbury Park.

Burawoy M. 2001. Manufacturing the global. Ethnography 2(2): 147-159.

Burawoy M, Blum JA, George S, Gille Z, Gowan T, Haney L, Klawiter M, Lopez SH, Riain SO, Thayer M. 2000. Global Ethnography: Forces, Connections, and Imaginations in a Post-Modern World. University of California Press: Berkeley.

Cooper F, Packard R. 1997a. Introduction. In International Development and the Social Sciences. Essays on the History and Politics of Knowledge, Cooper F, Packard R (eds). University of California Press: Berkeley; 1-41.

Cooper F, Packard R (eds). 1997b. International Development and the Social Sciences. Essays on the History and Politics of Knowledge. University of California Press: Berkeley.

DiBella A. 1992. Planned change in an organized anarchy: support for a post-modernist perspective. Journal of Organizational Change Management 5(3): 55-65.

Douglas M. 1992. Risk and Blame: Essays in Cultural Theory. Routledge: London.

Dowling G. 2001. Creating Corporate Reputations: Identity, Image and Performance. University Press: Oxford.

Drinkwater M. 1991. The State and Agrarian Change in Zimbabwe's Communal Areas. Macmillan: London.

Escobar A. 1995. Encountering Development: The Making and Unmaking of the Third World Princeton University Press: Princeton. 
Ferguson J. 1997. Anthropology and its evil twin: development in the constitution of a discipline. In International Development and the Social Sciences. Essays on the History and Politics of Knowledge, Cooper F, Packard R (eds). University of California Press: Berkeley; 150-175.

Ferguson J. 1990. The Anti-Politics Machine: Development, Depoliticization and Bureaucratic Power in Lesotho. University Press: Cambridge; University Press: Minnesota.

Gardner K, Lewis D. 1996. Anthropology, Development and the Postmodern Challenge. Pluto Press: London.

Gardner K, Lewis D. 2000. Development paradigms overturned or business as usual? Development discourse and the UK White Paper on International Development. Critique of Anthropology 20(1): $15-29$.

Giddens A. 1979. Central Problems in Social Theory: Action, Structure and Contradiction in Social Analysis. Macmillan: London.

Goldman M. 2001. The birth of a discipline. Producing authoritative green knowledge, World Bank style. Ethnography 2(2): 191-217.

Grindle MS. 1997. Divergent cultures?: when public organizations perform well in developing countries. World Development 25(4): 481-496.

Handy C. 1988. Understanding Voluntary Organizations. Penguin: Harmondsworth.

Harriss J. 1997. The Making of Rural Development: actors, arenas and paradigms. Paper for the Anniversary symposium of the Department of Rural Sociology, Wageningen University, June.

Hatch MJ. 1997. Organisation Theory: Modern Symbolic and Post-modern Perspectives. Oxford University Press: Oxford.

Hawkins P. 1997. Organizational culture: sailing between evangelism and complexity. Human Relations 50(4): 417-440.

Hebinck P, Verschoor G (eds). 2001. Resonances and Dissonances in Development. Actors, Networks and Cultural Repertoires. Royal Van Gorcum: Assen.

Hofstede G. 1991. Culture and Organizations: Software of the Mind. McGraw Hill: Maidenhead.

Kanbur R. 2002. IFI's and IPG's: operational implications for the World Bank. Working Paper WP 2002-17, Department of Applied Economics and Management, Cornell University.

Kotter J, Heskett J. 1992. Corporate Culture and Performance. The Free Press: New York.

Kuper A. 1999. Culture: The Anthropologist's Account. Harvard University Press: Cambridge.

Laurent P-J. 1998. Une Association de Dévelopement en Pays Mossi: le Don Comme Ruse. Karthala: Paris.

Lewis D. 1998a. Partnership as process: building an institutional ethnography of an inter-agency aquaculture project in Bangladesh. In Development as Process: Concepts and Methods for Working with Complexity Mosse D, Farrington J, Rew A (eds). Routledge: London; 99-114.

Lewis D. 1998b. Nonprofit organizations, business and the management of ambiguity: case studies of Fair Trade from Nepal and Bangladesh. Nonprofit Management and Leadership 9(2): 135-152.

Lewis D (ed.). 1999a. International Perspectives on Voluntary Action: Reshaping the Third Sector. Earthscan: London.

Lewis D. 1999b. Revealing, widening, deepening?: a review of the existing and potential contribution of anthropological approaches to third sector research. Human Organization 58(1): 73-81.

Lewis D. 2001. The Management of Non-Governmental Development Organizations: An Introduction. Routledge: London.

Lewis D. 2002. Organization and management in the third sector: towards a cross-cultural research agenda. Nonprofit Management and Leadership 13(1): 67-83.

Long N. 1992. From paradigm lost to paradigm regained? The case for an actor-oriented sociology of development. In Battlefields of Knowledge: The Interlocking of Theory and Practice in Social Research and Development, Long N, Long A (eds). Routledge: London; 16-43. 
Long N, Long A (eds). 1992. Battlefields of Knowledge: The Interlocking of Theory and Practice in Social Research and Development. Routledge: London.

Lund C. 1998. Law, Power and Politics in Niger-Land Struggles and the Rural Code. Hamburg: LIT Verlag.

Markowitz L. 2001. Finding the field: notes on the ethnography of NGOs. Human Organization 60(1): 40-46.

Martin J. 2002. Organizational Culture: Mapping the Terrain. Sage Publications: Thousand Oaks/ London/New Delhi.

Maxwell S. 1997. Implementing the world food summit plan of action. Food Policy, 22(6): 515-533.

Moore M. 2001. Empowerment at last? Journal of International Development 13: 321-329.

Moore SF. 2001. The international production of authoritative knowledge; the case of droughtstricken West Africa. Ethnography 2(2): 161-189.

Morgan G. 1997. Images of Organization, 2nd edn. Sage: London.

Nuijten M. 2001. Organisation and development: a practice perspective. In Resonances and Dissonances in Development. Actors, Networks and Cultural Repertoires, Hebinck P, Verschoor G (eds). Van Gorcum: Assen; 139-152.

Nuijten M. 1992. Local organization as organizing practices. Rethinking rural institutions. In Battlefields of Knowledge: The Interlocking of Theory and Practice in Social Research and Development, Long N, Long A (eds). Routledge: London; 189-207.

Olivier de Sardan J-P. 1995. Anthropologie et développement: Essai en socio-anthropologie du changement social. Karthala: Paris.

Peters T, Waterman R. 1982. In Search of Excellence: Lessons from America's Best-Run Companies. Harper and Row: New York.

Rhoades R. 1984. Breaking New Ground: Agricultural Anthropology. International Potato Center: Lima.

Scott JC. 1998. Seeing Like a State: How Certain Schemes to Improve the Human Condition Have Failed. Yale University Press: New Haven, CT.

Sikkink K. 1997. Development Ideas in Latin America: Paradigm Shift and the Economic Commission for Latin America. In International Development and the Social Sciences. Essays on the History and Politics of Knowledge, Cooper F, Packard R (eds). University of California Press: Berkeley; 228-256.

Tendler J. 1997. Good Government in the Tropics. Johns Hopkins University Press: Baltimore.

Wade RH. 1996. Japan, the World Bank, and the art of paradigm maintenance: The East Asian Miracle in Political Perspective. New Left Review 217: 3-36.

Wade RH. 1997. Greening the Bank: the struggle over the Environment 1970-1995. In The World Bank: Its First Half Century, Vol. 2, Kapur D, Lewis J, Webb R (eds). Brookings Institution Press; 611-734.

Wade RH. 2003. Governing the environment: the World Bank and the struggle to redefine development. Unpublished manuscript.

Watts M. 2001. Development Ethnographies. Ethnography 2(2): 283-300.

Wood G. 1997. States without citizens. In Too Close for Comfort?: NGOs, States and Donors, Hulme D, Edwards M (eds). Macmillan: London; 79-92.

World Bank. 2000. World Development Report 2000/2001: Attacking Poverty. World Bank: Washington, DC.

Worsley P. 1999. Culture and development theory. In Culture and Global Change, Skelton T, Allen T (eds). Routledge: London; 30-42.

Wright S (ed.). 1994. Anthropology of Organizations. Routledge: London. 